Sains Malaysiana 47(9)(2018): 2171-2178

http://dx.doi.org/10.17576/jsm-2018-4709-27

\title{
Puncture Resistance and Mechanical Properties of Graphene Oxide Reinforced Natural Rubber Latex
}

(Rintangan Tusukan dan Sifat Mekanik Lateks Getah Asli Berpengisi Oksida Grafin)

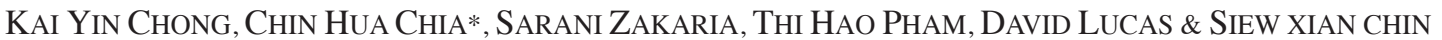

\begin{abstract}
Natural rubber (NR) latex gloves are widely used as a very important barrier for healthcare workers. However, they can still be perforated easily by sharp devices and instruments. The aim of this study was to investigate the effect of the addition of graphene oxide (GO) to low-ammonia NR latex on its puncture resistance, mechanical properties and thermal stability. GO was synthesized using modified Hummers' reaction. The produced GO was mixed into the NR latex solution at various doses (0.01-1.0 wt. \%), followed by a coagulant dipping process using ceramic plates to produce film samples. Puncture resistance was enhanced by $12 \%$ with $1.0 \mathrm{wt} . \%$ GO/NR. Also, the incorporation of GO improved the stress at $300 \%$ and $500 \%$, the modulus at $300 \%$ and $500 \%$ and the tear strength of low-ammonia NR latex films.
\end{abstract}

Keywords: Graphene oxide; natural rubber latex; puncture; tear strength; tensile strength

ABSTRAK

Sarung tangan lateks getah asli telah digunakan meluas sebagai perlindungan yang penting bagi pekerja penjagaan perubatan. Namun sarung tangan lateks getah asli masih mudah tertusuk oleh benda runcing dan tajam. Objektif kajian ini adalah untuk mengkaji kesan penambahan grafin oksida ke atas rintangan tusukan, sifat mekanik dan kestabilan terma. Dalam kajian ini, GO telah disintesis dengan menggunakan kaedah Hummers terubah suai. Kuantiti Go yang berlainan (0.01-1.0\% bt.) telah dicampur ke dalam lateks getah asli dan sampel filem dihasilkan melalui proses pencelupan. Keputusan yang diperoleh telah menunjukkan peningkatan yang ketara sebanyak $12 \%$ bagi sampel $1.0 \%$ bt. GO/NR dalam rintangan tusukan. Selain itu, penambahan GO dalam NR juga turut meningkatkan tegasan pada 300\%, tegasan pada 500\%, modulus pada $300 \%$ dan $500 \%$ serta cabikan.

Kata kunci: Cabikan; grafin oksida; kekuatan tegangan; lateks getah asli; penusukan

\section{INTRODUCTION}

Percutaneous injuries are penetration of the skin caused by sharp instruments, such as catheters, scalpels and hypodermic needles and are an increasingly encountered mechanical hazard suffered by healthcare workers (HCWs) (Nguyen et al. 2004; Valls et al. 2007). Percutaneous exposure to blood and body fluids between HCWs and patients can cause blood-borne diseases-for example, hepatitis B virus (HBV), hepatitis C virus ( $\mathrm{HCV}$ ) and human immunodeficiency virus (HIV) (Bricout et al. 2003; Chacko \& Isaac 2007). According to the World Health Organization (WHO), in 2003, about $37.6 \%$ of Hepatitis B, 39\% of Hepatitis $\mathrm{C}$ and $4.4 \%$ of HIV/AIDS cases in HCWs around the world were caused by needle stick injuries (Prüss-Üstün et al. 2003). Therefore, protective gloves must be punctureresistance to protect $\mathrm{HCWs}$.

Natural rubber (NR) latex gloves have been used widely by HCWs as a protective barrier against infections (Yip \& Cacioli 2002). However, this barrier is easily breached by sharp surgical devices and instruments and sometimes, the perforation may not be realized (Manson et al. 1995). Hence, techniques, such as wearing double gloves, are commonly used and have increased the prevention of needle stick injuries, providing $>90 \%$ protection to surgeons (Leslie et al. 1996; Makama et al. 2016). However, double gloves cause the loss of tactile sensation and create discomfort during surgical operations and surgical needles still can penetrate them (Kuroyanagi et al. 2012; Makama et al. 2016).

Graphene, a thin-layer 2D nanostructure with a high specific surface area, is a promising candidate as nanofiller in polymer nanocomposites to improve the mechanical properties, conductivity and permeability of polymers (Cui et al. 2016; Vuluga et al. 2011; Wissert et al. 2010). However, graphene has poor dispersion in polymer matrices, especially hydrophilic polymers, due to the lack of functional groups, agglomeration and restacking after reduction (Das et al. 2011; Kim et al. 2013; Liu et al. 2010). In contrast to graphene, graphene oxide (GO) is more compatible with polymer matrices due to its abundance of oxygen functional groups, such as epoxy, hydroxyl and carboxyl groups. It can prevent aggregation among graphene sheets and can thus disperse well in water and organic solvents (Bai et al. 2011; Cheng et al. 2012; Zhang et al. 2016). Graphene and GO have been used to improve the mechanical properties of polymer 
nanocomposites (Kang et al. 2017; Noël et al. 2014; Park et al. 2014; Wu et al. 2013; Yaragalla et al. 2015; Yin et al. 2016). Nevertheless, there is little information regarding the puncture resistance of filler-reinforced NR latex.

In this study, GO was produced using modified Hummer's method and added into the low ammonia (LA, $\sim .3 \%$ ) NR latex by solution mixing method to obtain a well-dispersed GO/NR latex suspension. The role of ammonia as a stabilizing agent to insure alkalinity of NR latex during storage to prevent premature coagulant and inhibit the bacteria growth. LA-NR latex is preferred instead of high ammonia (HA) NR latex with the ammonia content at least $0.6 \%$. The high concentration of ammonia is harmful to worker, irritation, corrodes equipment and environment pollutant in enclosed spaces. Compare to HANR latex, the LA-NR latex have shorter time preservation and poorer aging in some finished products (Guo et al. 2013; Karl Booten et al. 2010; Wang et al. 2015). The effects of GO loading (\%) in the NR latex on puncture resistance, tensile strength, tear strength and thermal stability were investigated.

\section{MATERIALS AND METHODS}

\section{PREPARATION OF GRAPHENE OXIDE (GO)}

GO was prepared from graphite flakes by modified Hummer's method. Briefly, $3 \mathrm{~g}$ of graphite flakes (SigmaAldrich, 332461, 100 mesh, $\geq 75 \%$ ) and $18 \mathrm{~g}$ of $\mathrm{KMnO}_{4}$ (99.9\%, Merck, purity) were added slowly into a beaker containing a concentrated acid solution of $\mathrm{H}_{2} \mathrm{SO}_{4}: \mathrm{H}_{3} \mathrm{PO}_{4}$ (360 mL:40 mL). The suspension was stirred at room temperature for 3 days. The reaction was terminated by adding $32 \mathrm{~mL} \mathrm{H}_{2} \mathrm{O}_{2}$ (30\%, Merck) with $900 \mathrm{~mL}$ deionized water containing ice cubes. The obtained graphite oxide slurry was washed and centrifuged with diluted aqueous $\mathrm{HCl}$ solution (37\%, R\&M Chemicals) at least 5 times to remove metal ions and acids. Finally, GO was obtained after repeat washes with deionized water until it was neutral.

\section{PREPARATION OF GO/NR LATEX FILM}

Low-ammonia pre-vulcanized natural rubber latex (LA-NR, 60 wt. \%) was supplied by Ansell NP Sdn. Bhd., Malaysia. GO/NR latex film was prepared by mixing GO into the NR latex with slow speed stirring. The desired amount of GO was first dispersed in DI water and added to the NR latex with mechanical stirring to produce homogenous mixtures. $\mathrm{GO} / \mathrm{NR}$ latex films with various contents of $\mathrm{GO}(0.01$ to 1.0 wt. \%) were produced by coagulant dipping method. First, the ceramic plate was pre-heated at $60^{\circ} \mathrm{C}$ in an oven. The plate was dipped into the latex coagulant at $50^{\circ} \mathrm{C}$ and dried in an oven at $60^{\circ} \mathrm{C}$ for $5 \mathrm{~min}$. The plate was then dipped into a latex bath containing GO and dried in an oven at $60^{\circ} \mathrm{C}$ for $5 \mathrm{~min}$. Next, the plate was pre-leached in a distilled water bath at $60^{\circ} \mathrm{C}$ for $10 \mathrm{~min}$. Finally, the plate was heated at $118^{\circ} \mathrm{C}$ for $32 \mathrm{~min}$. After post-leaching for $2 \mathrm{~min}$, the film samples were air dried. Before peeling off the films from the former, calcium carbonate powder was spread on the surface of the film samples using a brush to reduce the stickiness of the samples.

\section{CHARACTERIZATION}

The morphology of the graphite flakes was observed under a field emission scanning electron microscope (Zeiss, SUPRA 55VP). TEM images of the produced GO were taken under a transmission electron microscope (Hitachi, HT7700). GO was deposited onto a lacey carbon-coated copper grid prior to the observation. Tapping-mode atomic force microscope (AFM) images of the GO samples, which were deposited onto a mica sheet, were obtained using an atomic force microscope (Hitachi, AFM5000II). X-ray diffraction (XRD) patterns of the GO were obtained using an X-ray diffractometer (Bruker, D8-Advance) with $\mathrm{Cu}$ $K \alpha$ radiation $(\lambda=0.15406 \mathrm{~nm})$. The FTIR spectrum was obtained using an FTIR spectrometer (Bruker, Alpha). Raman measurements were made using a Raman microspectroscope ( $u$ Raman-Ci, Technospex) equipped with a $532 \mathrm{~nm}$ laser and an optical microscope (Nikon Eclipse $\mathrm{Ci}-\mathrm{L})$. The laser power was maintained between 0.5 and $1.0 \mathrm{~mW}$, with exposure times ranging from 1 to $5 \mathrm{~s}$ to avoid laser-induced heating of the sample.

The mechanical properties (tensile, tear and puncture resistance) of the GO/NR latex films were measured on a universal testing machine (Gotech Al3000) that was equipped with a $100 \mathrm{~N}$ load cell at a cross-head speed of $500 \mathrm{~mm} / \mathrm{min}$. Puncture tests were performed according to ASTM F1342. A puncture needle probe A (round tip: R $0.010 \pm 0.001^{\prime \prime}$, length $2.00 \pm 0.062^{\prime \prime}$, diameter $0.080 \pm$ $\left.0.002^{\prime \prime}\right)$ was attached to the tensile joint and the locknut was screwed. The needle was moved downward onto the test specimen to allow the crosshead to build up the desired velocity prior to impacting the test specimen. The tensile and tear strengths of the samples were measured following ISO 10282 (with extensometer) and ASTM D 624 with a type $\mathrm{C}$ die cut (V-shaped die), respectively. The results were calculated and presented in respective tables. Statistical analyses were carried out using t-test. Statistical significance was defined at $p<0.05$. Thermal gravity analysis (TGA) was carried out ranging from room temperature to $700^{\circ} \mathrm{C}$ at a heating rate of $10^{\circ} \mathrm{C} / \mathrm{min}$ using a Mettler Toledo (TGA/SDTA 851).

\section{RESULTS AND DISCUSSION}

Figure 1(a) shows that the raw graphite flakes consisted of multiple layers of graphene sheets. When the graphite flakes underwent Hummers' reaction, thin, wrinkled and folded sheets of GO were produced, as shown in Figure 1(b). After the oxidation reaction, the XRD diffraction peak of graphite (Figure 1(c)) was shifted from $26.6^{\circ}$ to $9.5^{\circ}$, indicating the expansion of d-spacing from 0.34 to $0.93 \mathrm{~nm}$. The expansion of the interlayer spacing was due to the introduction of oxygenated functional groups on its surface (Bai et al.2011). The presence of oxygen functional 
group on GO was confirmed by the FTIR results in Figure 1(d), showing the presence of $\mathrm{C}=\mathrm{O}$ stretching vibration at $1726.8 \mathrm{~cm}^{-1}$, a C-O (epoxy) stretching peak at 1611.8 $\mathrm{cm}^{-1}$, a C-O (alkoxy) stretching peak at $1039.7 \mathrm{~cm}^{-1}$ and vibration and deformation peaks of $\mathrm{O}-\mathrm{H}$ groups at 3222.2 and $1420.3 \mathrm{~cm}^{-1}$ (Javed \& Hussain 2015; You et al. 2013). A typical tapping mode AFM image of GO is presented in Figure 1(e), with an estimated thickness of $1.02 \mathrm{~nm}$, which is characteristic of a single-layer GO sheet (Huang et al. 2011; Shao et al. 2012).

The Raman spectrum shown in Figure 1(f) also reflects the structural change of graphite into GO. The spectrum of graphite flakes shows a strong $\mathrm{G}$ band at $1581 \mathrm{~cm}^{-1}$, a D band at $1344 \mathrm{~cm}^{-1}$ and a $2 \mathrm{D}$ band at $2717 \mathrm{~cm}^{-1}$. GO exhibited a $\mathrm{G}$ band and $\mathrm{D}$ band at 1591 and $1354 \mathrm{~cm}^{-1}$, respectively. The $\mathrm{G}$ band and $2 \mathrm{D}$ band are due to first-order scattering of the $\mathrm{E}_{2 \mathrm{~g}}$ mode and second-order zone boundary phonons, respectively (Krishnamoorthy et al. 2013; Zhu et al. 2010). The $\mathrm{G}$ band of the GO shifted toward a higher wave number compared with graphite flakes, reflecting the formation of $\mathrm{sp}^{3}$ carbon atoms during the oxidation of graphite (Krishnamoorthy et al. 2013; Nanda et al. 2016). The D band was broader and higher in intensity for GO, indicating a decrease in the size of the in-plane $\mathrm{sp}^{2}$ domains (Nanda et al. 2016) and the presence of defects caused by the introduction of oxygen functional groups during oxidation (Wang et al. 2015; Yang et al. 2009). The decrease in intensity of the 2D band of GO was due to breaking of the stacking order of the graphite during the reaction (Vuluga et al. 2011). The integrated intensity ratio of the $\mathrm{D}$ and $\mathrm{G}$ bands $\left(\mathrm{I}_{\mathrm{D}} / \mathrm{I}_{\mathrm{G}}\right)$ increased from 0.21 to 1.13 after the oxidation reaction, indicating the presence of defects in the graphene sheets from the oxidation process (Wu et al. 2015).

\section{PUNCTURE RESISTANCE OF GO/NR LATEX FILMS}

The maximum puncture force of the various wt. \% GO/ NR latex films is shown in Table 1. In this study, the force required to penetrate the sample films is depending on the
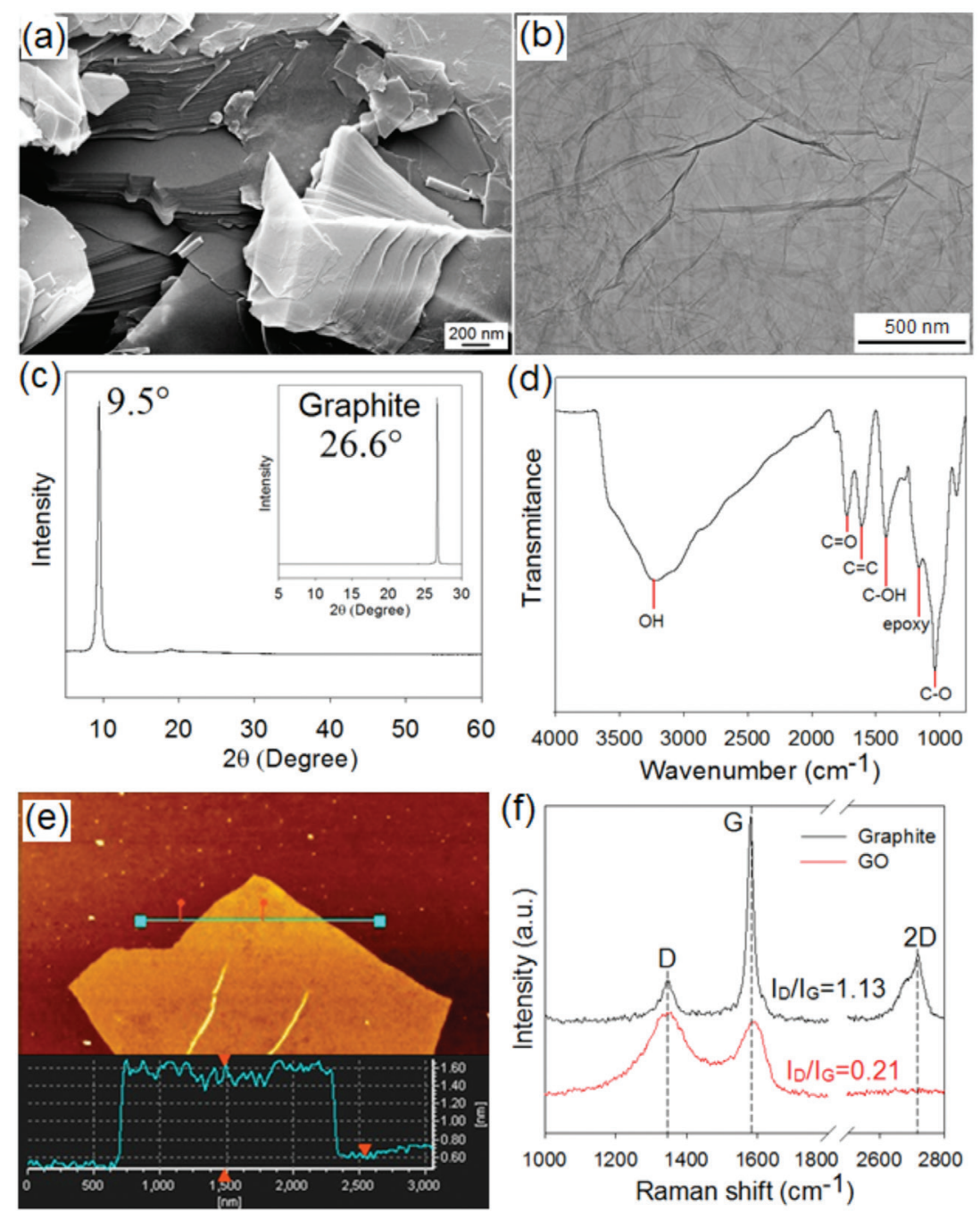

FIGURE 1. (a) FESEM image of graphite flakes. (b) TEM images, (c) XRD diagram, (d) FTIR spectrum and

(e) AFM image of the produced GO. The inset of (c) is the XRD spectrum in the graphite flakes and

(f) Raman spectra of graphite and GO 
TABLE 1. Thickness, displacement, and maximum puncture force of GO/NR latex films

\begin{tabular}{cccc}
\hline $\begin{array}{c}\text { GO } \\
(\text { wt. \%) }\end{array}$ & $\begin{array}{c}\text { Thickness } \\
(\mathrm{mm})\end{array}$ & $\begin{array}{c}\text { Displacement } \\
(\mathrm{mm})\end{array}$ & $\begin{array}{c}\text { Puncture force } \\
(\mathrm{N})\end{array}$ \\
\hline Control & $0.39 \pm 0.01$ & $19.9 \pm 1.1$ & $7.6 \pm 0.7$ \\
0.01 & $0.40 \pm 0.01$ & $19.1 \pm 0.8$ & $7.7 \pm 0.4$ \\
0.05 & $0.39 \pm 0.01$ & $16.4 \pm 0.7$ & $6.6 \pm 0.3$ \\
0.10 & $0.38 \pm 0.01$ & $15.4 \pm 0.6$ & $7.3 \pm 0.7$ \\
0.50 & $0.48 \pm 0.01$ & $11.7 \pm 0.8$ & $8.8 \pm 0.6$ \\
1.00 & $0.45 \pm 0.02$ & $9.8 \pm 0.4$ & $8.5 \pm 0.6$ \\
\hline
\end{tabular}

sample thickness and the interaction between GO and NR latex. According to the t-test results, the addition of 0.5 and $1.0 \mathrm{wt} . \%$ GO has significantly increased the puncture resistance of NR latex films, approximately $12-15 \%$ increment compared to control sample. The increase in sample thickness is due to the increased GO contents in the NR latex. As shown in Figure 1, the single and large area of GO with various oxygen functional groups are well dispersed in aqueous solution which can enhance the strong physical interaction between GO and NR latex (Forati et al. 2014). The decrease in puncture resistance at low GO contents may due to insufficient of GO to provide full coverage of the NR latex films (Guan et al. 2016). At high concentration of GO in NR latex, the GO aligned in lamellar arrangement in the NR latex, resulting in thicker and stiffer films. Hence, the puncture force increased with the decrease in penetration displacement (as shown in Figure 2(a)) due to the well load transfer and distribution between GO and NR latex particles. The incorporation of
GO (0.5 \& 1.0 wt. \%) in NR latex has provided an addition barrier in reduced the penetration force on sample films.

\section{TENSILE PROPERTIES OF GO/NR LATEX FILMS}

The effects of GO loading on the tensile strength and tear strength of NR latex films are depicted in Table 2 and Figure 3 . The slope of the diagram increased with GO loading in NR latex implied that the enhanced stiffness of NR latex films as shown in Figure 3(b) and 3(d). As the GO is further added into the NR latex, the ultimate tensile strength and elongation of NR latex films reduced but increased in $\mathrm{M} 300 \%$ and $\mathrm{M} 500 \%$ compare to control sample. The reduction of tensile strength was observed in 0.01-0.05 wt. $\% \mathrm{GO} / \mathrm{NR}$ latex films may due to the end chain cross-linking system of NR disturbed by the low GO content, which could render to lower mechanical properties (Hernández et al. 2012). The reduction of stress at $700 \%$ for $1.0 \mathrm{wt} . \% \mathrm{GO} / \mathrm{NR}$ may due to the agglomeration at high GO concentrations,
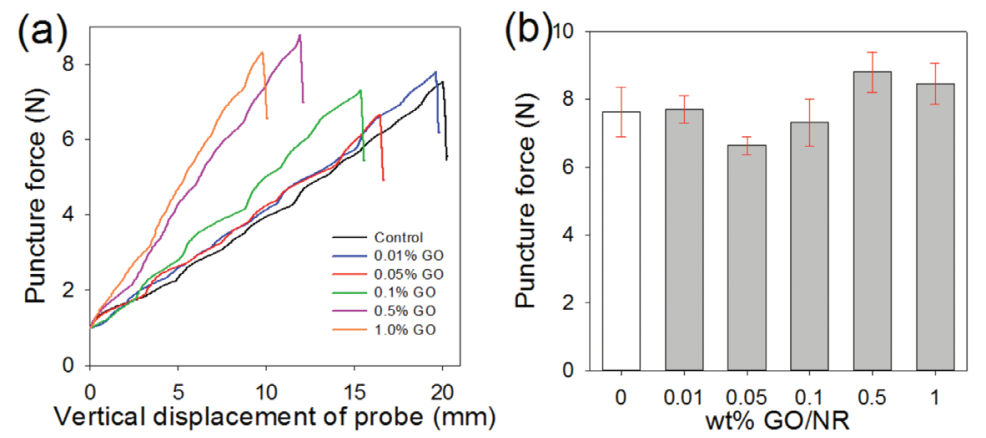

FIGURE 2. Comparison of (a) puncture-displacement curve and (b) puncture force of NR latex films containing various contents of GO

TABLE 2. Mechanical properties of GO/NR latex film

\begin{tabular}{ccccccccc}
\hline $\begin{array}{c}\text { GO } \\
(\text { wt. } \%)\end{array}$ & $\begin{array}{c}\text { Tensile } \\
\text { strength } \\
(\mathrm{MPa})\end{array}$ & $\begin{array}{c}\text { Elongation } \\
(\%)\end{array}$ & $\begin{array}{c}\text { Stress@ } \\
300 \% \\
(\mathrm{MPa})\end{array}$ & $\begin{array}{c}\text { Stress@ } \\
500 \% \\
(\mathrm{MPa})\end{array}$ & $\begin{array}{c}\text { Stress@ } \\
700 \% \\
(\mathrm{MPa})\end{array}$ & $\begin{array}{c}\text { M300\% } \\
(\mathrm{MPa})\end{array}$ & $\begin{array}{c}\text { M500\% } \\
(\mathrm{MPa})\end{array}$ & $\begin{array}{c}\text { Tear } \\
\text { strength } \\
(\mathrm{N} / \mathrm{mm})\end{array}$ \\
\hline Control & $30.1 \pm 1.5$ & $775.6 \pm 14.4$ & $1.3 \pm 0.1$ & $4.4 \pm 0.3$ & $20.2 \pm 1.1$ & $0.4 \pm 0.1$ & $3.2 \pm 0.3$ & $38.2 \pm 1.0$ \\
0.01 & $31.2 \pm 0.9$ & $749.9 \pm 9.9$ & $1.4 \pm 0.1$ & $5.3 \pm 0.3$ & $23.8 \pm 1.1$ & $0.4 \pm 0.2$ & $3.5 \pm 0.3$ & $34.9 \pm 0.9$ \\
0.05 & $28.6 \pm 1.4$ & $738.9 \pm 10.6$ & $1.4 \pm 0.1$ & $5.5 \pm 0.4$ & $23.6 \pm 1.3$ & $0.4 \pm 0.2$ & $3.8 \pm 0.3$ & $33.7 \pm 1.6$ \\
0.10 & $31.2 \pm 1.1$ & $755.4 \pm 6.1$ & $1.8 \pm 0.1$ & $6.3 \pm 0.2$ & $22.4 \pm 1.3$ & $0.5 \pm 0.1$ & $4.1 \pm 0.2$ & $40.9 \pm 0.9$ \\
0.50 & $26.7 \pm 1.2$ & $735.8 \pm 7.5$ & $2.8 \pm 0.1$ & $7.9 \pm 0.3$ & $23.2 \pm 1.0$ & $0.8 \pm 0.1$ & $4.1 \pm 0.2$ & $43.6 \pm 1.1$ \\
1.0 & $22.8 \pm 0.9$ & $685.4 \pm 17.0$ & $3.7 \pm 0.3$ & $9.7 \pm 0.7$ & $15.7 \pm 6.5$ & $1.2 \pm 0.2$ & $4.5 \pm 0.3$ & $50.7 \pm 1.2$ \\
\hline
\end{tabular}



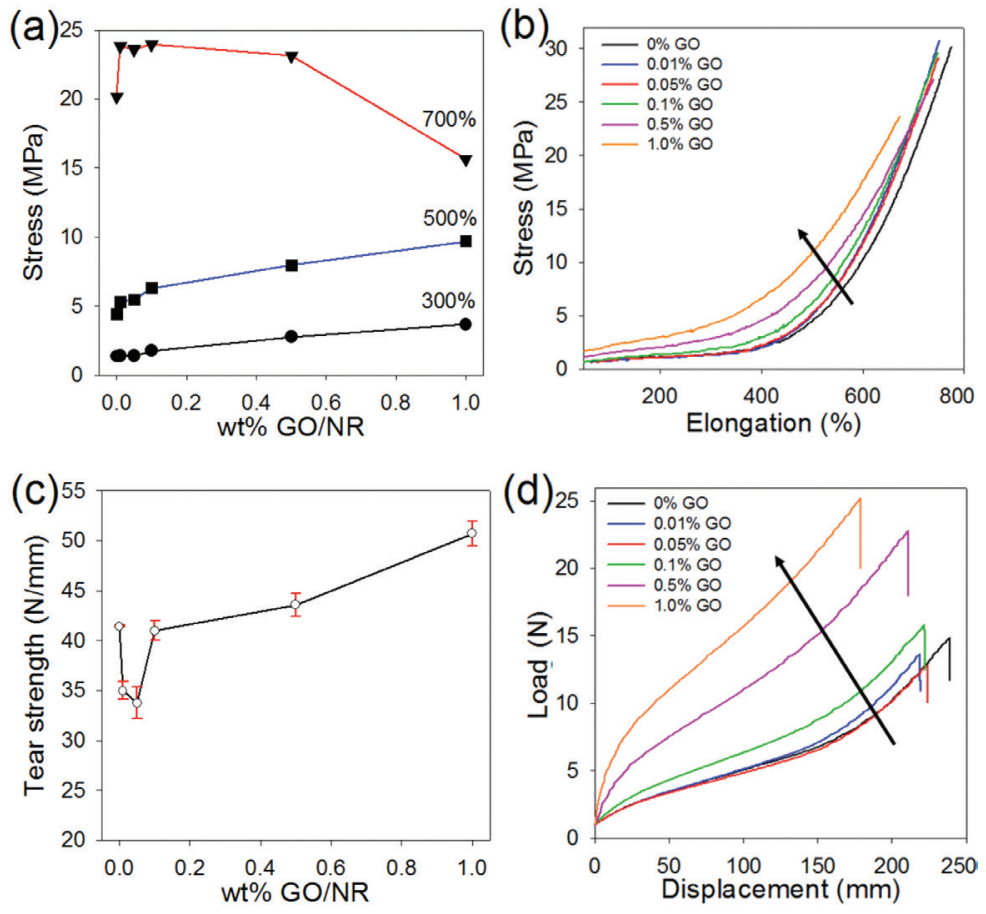

FIGURE 3. (a) Stress at 300, 500 and 700\% strain, (b) stress-strain curves and (c) comparison of tear strength and (d) tear load-displacement curve of the NR latex film samples containing different GO contents

resulting the limitation of the interfacial area between the filler and matrix for stress transfer (Moghaddam et al. 2014; Park et al. 2014). From the results, 1.0 wt. \% GO has achieved highest improvement in NR latex, which has significantly increased the stress at $300 \%$, stress at $500 \%$, M300 and M500 with 185\%, 120\%, 200\% and $41 \%$, respectively.

The improvement on the properties of the NR latex by GO can be attributed to the high degree of exfoliation of GO sheets though chemical oxidation reaction. As shown Figure 1, the large surface area and rich in wrinkles of GO can provide good interaction between the GO sheets and NR particles through van der Waals interactions (Mao et al. 2013). The thin layer GO sheets with various oxygen functional groups on their surface allowed stable dispersion of GO in NR latex (alkaline condition, $\mathrm{pH} \sim 11$ ). In addition, these functional groups also facilitate the interfacial adhesion between GO and NR latex (Guan et al. 2016; Mensah et al. 2014). Hence, excellent dispersion of GO in NR latex has resulted in efficient stress transfer and well distribution between filler and matrix (Dong et al. 2015; Forati et al. 2014; Mao et al. 2014; Mensah et al. 2014; Wu et al. 2015). Besides, the incorporation of GO into NR latex also improved the tear strength. The highest tear strength was 1.0 wt. $\%$ GO/NR latex with $\sim 33 \%$ enhancement as compared to the control sample, showing the excellent reinforcing efficiency of GO to NR latex by deviating the crack propagation due to the orientation of fillers along the stretching direction at the crack tip (Dong et al. 2017).

The thermal degradation behavior of the NR latex with increasing GO loadings is evaluated using thermogravimetric analysis (TGA) and the percentage weight loss of GO/NR latex is illustrated in Table 3 and Figure 4 . The residue weight was taken at temperature $340^{\circ} \mathrm{C}\left(\mathrm{R}_{340}\right), 404^{\circ} \mathrm{C}\left(\mathrm{R}_{404}\right)$ and $596^{\circ} \mathrm{C}\left(\mathrm{R}_{596}\right)$, which are corresponding to the initial degradation temperature, faster decomposition temperature and maximum degradation temperature, respectively. The TGA curve of GO/NR latex films with increased GO loading is found slightly lower at $\mathrm{R}_{340}$ and higher at $\mathrm{R}_{404}$ and $\mathrm{R}_{596}$ compared to control sample

TABLE 3. The TGA data of GO/NR latex films

\begin{tabular}{cccc}
\hline Sample & $\mathrm{R}_{340}($ wt. $\%)$ & $\mathrm{R}_{404}($ wt. \%) & $\mathrm{R}_{596}(\mathrm{wt} . \%)$ \\
\hline Control & 96.0 & 19.7 & 3.6 \\
$0.01 \%$ GO-MLA & 95.9 & 19.5 & 3.8 \\
$0.05 \%$ GO-MLA & 95.1 & 21.8 & 4.0 \\
$0.10 \%$ GO-MLA & 94.8 & 21.4 & 4.6 \\
$0.50 \%$ GO-MLA & 95.9 & 26.8 & 6.0 \\
$1.0 \%$ GO-MLA & 94.7 & 26.9 & 6.3 \\
\hline
\end{tabular}

$\left(\mathrm{R}_{340}, \mathrm{R}_{404}\right.$ and $\mathrm{R}_{596}:$ Residue weight at $340^{\circ} \mathrm{C}, 404^{\circ} \mathrm{C}$ and $596^{\circ} \mathrm{C}$, respectively) 


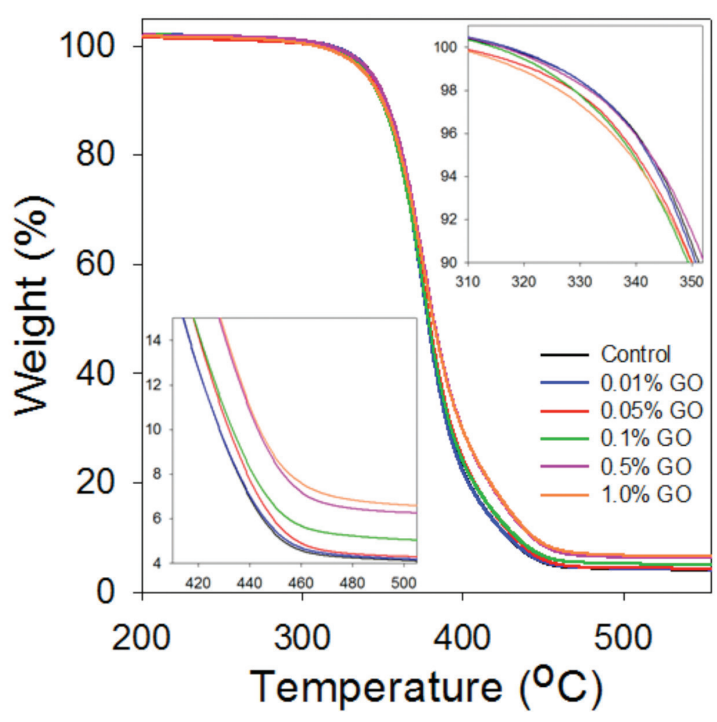

FIGURE 4. TGA curve of GO/NR latex films

as shown in the inset picture of Figure 4. At the maximum decomposition temperature $\left(596^{\circ} \mathrm{C}\right), 1.0 \mathrm{wt} . \%$ of $\mathrm{GO} / \mathrm{NR}$ latex film has higher weight residue $(6.3 \%)$ compared to control sample (3.6\%). The decrease in $\mathrm{R}_{340}$ of $\mathrm{GO} / \mathrm{NR}$ latex is mainly caused by the low degradation temperature of GO. While the increase in $\mathrm{R}_{404}$ and $\mathrm{R}_{596}$ is due to the physical barrier effect of GO, which retards the emission and dispersion of small gaseous molecules by forming a jammed network of layers (Bhawal et al. 2016; Yin et al. 2017). The enhanced thermal stability also proved the good dispersion of $\mathrm{GO}$ and strong interfacial interaction between GO and NR latex (Mensah et al. 2014; Xiong et al. 2013; Zhang et al. 2016).

\section{CONCLUSION}

Low ammonia NR latex films reinforced with GO were produced by solution mixing and coagulant dipping process. The TEM, XRD and Raman spectroscopy characterization illuminated the successful exfoliation of graphite flakes to GO with large surface area, thin and wrinkled layer. The various oxygen functional groups on the GO resulted in well dispersion of GO in the NR latex mixture. The incorporation of $1.0 \mathrm{wt} . \% \mathrm{GO}$ has enhanced tensile strength, tear strength and puncture resistant of NR latex films due to well dispersion of GO in NR latex and good interfacial adhesion between GO and NR latex particle. The thin and large surface area of GO also provide the physical interaction between GO and NR latex, leading to excellent load transfer in the GO/NR latex films.

\section{ACKNOWLEDGEMENTS}

The authors acknowledge the financial support provided by the research project grants ST-2015-012 and DIP-2015009. K.Y. Chong acknowledges the Ministry of Higher Education (MOE), Malaysia for the receipt of the MyPhD scholarship.

\section{REFERENCES}

Bai, X., Wan, C., Zhang, Y. \& Zhai, Y. 2011. Reinforcement of hydrogenated carboxylated nitrile-butadiene rubber with exfoliated graphene oxide. Carbon 49(5): 1608-1613.

Bhawal,P., Ganguly, S., Chaki, T.K. \& Das, N.C. 2016. Synthesis and characterization of graphene oxide filled ethylene methyl acrylate hybrid nanocomposites. RSC Adv. 6(25): 2078120790.

Bricout, F., Moraillon, A., Sonntag, P., Hoerner, P., Blackwelder, W. \& Plotkin, S. 2003. Virus-inhibiting surgical glove to reduce the risk of infection by enveloped viruses. Journal of Medical Virology 69(4): 538-545.

Guo, C., Zhou, L. \& Lv, J. 2013. Effects of expandable graphite and modified ammonium polyphosphate on the flame-retardant and mechanical properties of wood flour-polypropylene composites. Polymers and Polymer Composites 21(7): 449-456.

Chacko, J. \& Isaac, R. 2007. Percutaneous injuries among medical interns and their knowledge \& practice of post-exposure prophylaxis for HIV. Indian Journal of Public Health 51(2): 127-129.

Cheng, H.K.F., Sahoo, N.G., Tan, Y.P., Pan, Y., Bao, H., Li, L., Chan, S.H. \& Zhao, J. 2012. Poly(vinyl alcohol) nanocomposites filled with poly(vinyl alcohol)-grafted graphene oxide. ACS Applied Materials and Interfaces 4(5): 2387-2394.

Cui, Y., Kundalwal, S.I. \& Kumar, S. 2016. Gas barrier performance of graphene/polymer nanocomposites. Carbon 98: 313-333.

Das, S., Wajid, A.S., Shelburne, J.L., Liao, Y.C. \& Green, M.J. 2011. Localized in situ polymerization on graphene surfaces for stabilized graphene dispersions. ACS Applied Materials and Interfaces 3(6): 1844-1851.

Dong, B., Zhang, L. \& Wu, Y. 2017. Influences of different dimensional carbon-based nanofillers on fracture and fatigue resistance of natural rubber composites. Polymer Testing 63: 281-288.

Dong, B., Liu, C., Zhang, L. \& Wu, Y. 2015. Preparation, fracture, and fatigue of exfoliated graphene oxide/natural rubber composites. RSC Adv. 5(22): 17140-17148.

Forati, T., Atai, M., Rashidi, A.M., Imani, M. \& Behnamghader, A. 2014. Physical and mechanical properties of graphene oxide/polyethersulfone nanocomposites. Polymers for Advanced Technologies 25(3): 322-328.

Guan, Y., Meyers, K.P., Mendon, S.K., Hao, G., Douglas, J.R., Trigwell, S., Nazarenko, S.I., Patton, D.L. \& Rawlins, J.W. 2016. Ecofriendly fabrication of modified graphene oxide latex nanocomposites with high oxygen barrier performance. ACS Applied Materials and Interfaces 8(48): 33210-33220.

Hernández, M., del Mar Bernal, M., Verdejo, R., Ezquerra, T.A. \& López-Manchado, M.A. 2012. Overall performance of natural rubber/graphene nanocomposites. Composites Science and Technology 73(1): 40-46.

Huang, N., Lim, H., Chia, C.H., Yarmo, M.A. \& Muhamad, M. 2011. Simple room-temperature preparation of highyield large-area graphene oxide. International Journal of Nanomedicine 6: 3443-3448.

Javed, S.I. \& Hussain, Z. 2015. Covalently functionalized graphene oxide-characterization and its electrochemical performance. International Journal of Electrochemical Science 10(11): 9475-9487.

Kang, H., Tang, Y., Yao, L., Yang, F., Fang, Q. \& Hui, D. 2017. Fabrication of graphene/natural rubber nanocomposites with 
high dynamic properties through convenient mechanical mixing. Composites Part B: Engineering 112: 1-7.

Karl Booten, G., Yatim, A.H.B. \& Singh, M. 2010. Natural Rubber Latex Preservation. United States Patent Application Publication US 2010/02.

Kim, K.H., Yang, M., Cho, K.M., Jun, Y.S., Lee, S.B. \& Jung, H.T. 2013. High quality reduced graphene oxide through repairing with multi-layered graphene ball nanostructures. Scientific Reports 3: 3251.

Krishnamoorthy, K., Veerapandian, M., Yun, K. \& Kim, S.J. 2013. The chemical and structural analysis of graphene oxide with different degrees of oxidation. Carbon 53: 38-49.

Kuroyanagi, N., Nagao, T., Sakuma, H., Miyachi, H., Ochiai, S., Kimura, Y., Fukano, H. \& Shimozato, K. 2012. Risk of surgical glove perforation in oral and maxillofacial surgery. International Journal of Oral and Maxillofacial Surgery 41(8): 1014-1019.

Leslie, L.F., Woods, J.A., Thacker, J.G., Morgan, R.F., McGregor, W. \& Edlich, R.F. 1996. Needle puncture resistance of surgical gloves, finger guards, and glove liners. Journal of Biomedical Materials Research Part A 33(1): 41-46.

Liu, L.H.,Lerner, M.M. \& Yan, M. 2010. Derivitization of pristine graphene with well-defined chemical functionalities. Nano Letters 10(9): 3754-3756.

Makama, J.G., Okeme, I.M., Makama, E.J. \& Ameh, E.A. 2016. Glove perforation rate in surgery: A randomized, controlled study to evaluate the efficacy of double gloving. Surgical Infections 17(4): 436-442.

Manson, T.T., Bromberg, W.G., Thacker, J.G., McGregor, W., Morgan, R.F. \& Edlich, R.F. 1995. A new glove puncture detection system. The Journal of Emergency Medicine 13(3): 357-364.

Mao, Y., Zhang, S., Zhang, D., Chan, T.W. \& Liu, L. 2014. Enhancing graphene oxide reinforcing potential in composites by combined latex compounding and spray drying. Materials Research Express 1(2).

Mao, Y., Wen, S., Chen, Y., Zhang, F., Panine, P., Chan, T.W., Zhang, L., Liang, Y. \& Liu, L. 2013. High performance graphene oxide based rubber composites. Scientific Reports 3: 2508.

Mensah, B., Kim, S., Arepalli, S. \& Nah, C. 2014. A study of graphene oxide-reinforced rubber nanocomposite. Journal of Applied Polymer Science 131(16): 1-9.

Moghaddam, S.Z., Sabury, S. \& Sharif, F. 2014. Dispersion of rGO in polymeric matrices by thermodynamically favorable self-assembly of GO at oil-water Interfaces. RSC Advances 4(17): 8711-8719.

Nanda, S.S., Yi, D.K. \& Kim, K. 2016. Study of antibacterial mechanism of graphene oxide using raman spectroscopy. Scientific Reports 6: 28443

Nguyen, C., Vu-Khanh, T. \& Lara, J. 2004. Puncture characterization of rubber membranes. Theoretical and Applied Fracture Mechanics 42(1): 25-33.

Noël, A., Faucheu, J., Chenal, J.M., Viricelle, J.P. \& BourgeatLami, E. 2014. Electrical and mechanical percolation in graphene-latex nanocomposites. Polymer (United Kingdom) 55(20): 5140-5145.

Park, O.K., Kim, S.G., You, N.H., Ku, B.C., Hui, D. \& Lee, J.H. 2014. Synthesis and properties of iodo functionalized graphene oxide/polyimide nanocomposites. Composites Part B: Engineering 56: 365-371.

Prüss-Üstün, A., Rapiti, E. \& Hutin, Y.J. 2003. Sharps injuries: Global burden of disease from sharps injuries to health-care workers. Environmental Burden of Disease Series No. 3. World Health Organization.

Shao, G., Lu, Y., Wu, F., Yang, C., Zeng, F. \& Wu, Q. 2012. Graphene oxide: The mechanisms of oxidation and exfoliation. Journal of Materials Science 47(10): 4400-4409.

Valls, V., Lozano, M.S., Yánez, R., Martínez, M.J., Pascual, F., Lloret, J. \& Ruiz, J.A. 2007. Use of safety devices and the prevention of percutaneous injuries among healthcare workers. Infection Control and Hospital Epidemiology 28(12): 1352-1360.

Vuluga, D., Thomassin, J.M., Molenberg, I., Huynen, I., Gilbert, B., Jerome, C., Alexandre, M. \& Detrembleur, C. 2011. Straightforward synthesis of conductive graphene/ polymer nanocomposites from graphite oxide. Chemical Communications 47(9): 2544-2546.

Wang, L., Cui, Y., Li, B., Yang, S., Li, R., Liu, Z., Vajtai, R. \& Fei, W. 2015. High apparent strengthening efficiency for reduced graphene oxide in copper matrix composites produced by molecule-lever mixing and high-shear mixing. RSC Advances 5(63): 51193-51200

Wang, T., Gui, H.X., Zhang, W.F., Zhang, K.X., Yu, W.Q., Li, Y.M., Zeng, R.Z. \& Huang, M.F. 2015. Novel nonammonia preservative for concentrated natural rubber latex. Journal of Applied Polymer Science 132(15): 6-11.

Wissert, R., Steurer, P., Schopp, S., Thomann, R. \& Mülhaupt, R. 2010. Graphene nanocomposites prepared from blends of polymer latex with chemically reduced graphite oxide dispersions. Macromolecular Materials and Engineering 295(12): 1107-1115.

Wu, J., Huang, G., Li, H., Wu, S., Liu, Y. \& Zheng, J. 2013. Enhanced mechanical and gas barrier properties of rubber nanocomposites with surface functionalized graphene oxide at low content. Polymer 54(7): 1930-1937.

Wu, R., Wang, Y., Chen, L., Huang, L. \& Chen, Y. 2015. Control of the oxidation level of graphene oxide for high efficiency polymer solar cells. RSC Advances 5(61): 49182-49187.

Wu, X., Lin, T.F., Tang, Z.H., Guo, B.C. \& Huang, G.S. 2015. Natural rubber/graphene oxide composites: Effect of sheet size on mechanical properties and straininduced crystallization behavior. Express Polymer Letters 9(8): 672-685.

Xiong, X., Wang, J., Jia, H., Fang, E. \& Ding, L. 2013. Structure, thermal conductivity, and thermal stability of bromobutyl rubber nanocomposites with ionic liquid modified graphene oxide. Polymer Degradation and Stability 98(11): 2208-2214.

Yang, D., Velamakanni, A., Bozoklu, G., Park, S., Stoller, M., Piner, R.D., Stankovich, S., Jung, I., Field, D.A. \& Ventrice, C.A. 2009. Chemical analysis of graphene oxide films after heat and chemical treatments by $\mathrm{x}$-ray photoelectron and micro-raman spectroscopy. Carbon 47(1): 145-152.

Yaragalla, S., Meera, A.P., Kalarikkal, N. \& Thomas, S. 2015. Chemistry associated with natural rubber-graphene nanocomposites and its effect on physical and structural properties. Industrial Crops and Products 74: 792-802.

Yin, B., Zhang, X., Zhang, X., Wang, J., Wen, Y., Jia, H., Ji, Q. \& Ding, L. 2017. Ionic liquid functionalized graphene oxide for enhancement of styrene-butadiene rubber nanocomposites. Polymers for Advanced Technologies 28(3): 293-302.

Yin, B., Wang, J., Jia, H., He, J., Zhang, X. \& Xu, Z. 2016. Enhanced mechanical properties and thermal conductivity of styrene-butadiene rubber reinforced with polyvinylpyrrolidone-modified graphene oxide. Journal of Materials Science 51(12): 5724-5737. 
Yip, E. \& Cacioli, P. 2002. The manufacture of gloves from natural rubber latex. Journal of Allergy and Clinical Immunology 110(2): S3-S14.

You, S., Luzan, S.M., Szabó, T. \& Talyzin, A.V. 2013. Effect of synthesis method on solvation and exfoliation of graphite oxide. Carbon 52: 171-180.

Zhang, C., Zhai, T., Dan, Y. \& Turng, L.S. 2016. Reinforced natural rubber nanocomposites using graphene oxide as a reinforcing agent and their in situ reduction into highly conductive materials. Polymer Composites 38: 199-207.

Zhu, Y., Murali, S., Cai, W., Li, X., Suk, J.W., Potts, J.R. \& Ruoff, R.S. 2010. Graphene and graphene oxide: Synthesis, properties, and applications. Advanced Materials 22(35): 3906-3924.

Kai Yin Chong, Chin Hua Chia*\& Sarani Zakaria

Materials Science Program

Faculty of Science and Technology

Universiti Kebangsaan Malaysia

43600 UKM Bangi, Selangor Darul Ehsan

Malaysia
Thi Hao Pham \& David Lucas

Medical Solutions Innovation Centre (R\&D)

Ansell N.P. Sdn. Bhd., Lot 80

Ayer Keroh Industrial Estate

75450 Melaka

Malaysia

Siew Xian Chin

ASASIpintar Program

Pusat PERMATApintar® Negara

Universiti Kebangsaan Malaysia

43600 UKM Bangi, Selangor Darul Ehsan

Malaysia

*Corresponding author; email: chia@ukm.edu.my

Received: 26 March 2018

Accepted: 23 May 2018 